UDC 37.013:004(510)

\author{
Kateryna P. Osadcha \\ Doctor of Pedagogical Sciences, Associate Professor, \\ Associate Professor at the Department of Informatics and Cybernetics \\ Bogdan Khmelnitsky Melitopol State Pedagogical University, Melitopol, Ukraine \\ ORCID ID 0000-0003-0653-6423 \\ okp@mdpu.org.ua
}

\author{
Viacheslav V. Osadchyi \\ Doctor of Pedagogical Sciences, Professor, Head of the Department of Informatics and Cybernetics \\ Bogdan Khmelnitsky Melitopol State Pedagogical University, Melitopol Ukraine \\ ORCID ID 0000-0001-5659-4774 \\ osadchyi@mdpu.org.ua \\ Oleg M. Spirin \\ Doctor of Pedagogical Sciences, Professor, Corresponding Member of the National Academy of Educational \\ Sciences of Ukraine, Vice-Rector for Research and Digitalization \\ SIHE "University of Educational Management" of NAES of Ukraine, Kyiv, Ukraine \\ ORCID ID 0000-0002-9594-6602 \\ oleg.spirin@gmail.com
}

\title{
CURRENT STATE AND DEVELOPMENT TRENDS OF E-LEARNING IN CHINA
}

\begin{abstract}
The emergence of new e-learning technologies requires a rethinking of their implementation in higher education. To fill this gap, this study analyzes the experience of using and creating e-learning tools in Chinese higher education institutions over the past 5 years. The survey found that the most common educational technologies in Chinese higher education are blended learning, collaborative learning, modified classes, micro-learning and adaptive learning, as well as e-learning tools such as mobile technology and mass open online courses. A survey of university faculty and students explored the practicalities of using e-learning tools in Chinese higher education. The results of the analysis of 20 responses from teachers and 16 responses from undergraduate and postgraduate students showed the following: the teachers have the opportunity to organize e-learning at their university, blended learning is mainly implemented in the learning process, teachers are not limited in choosing e-learning tools: video tools, messengers, social networks and e-learning tools such as Articulate 360 and Adapt. It has been proven that video lectures with a higher level of teacher expression were better than those that had a normal level of teacher expression and only audio, in terms of improving the level of students' emotional and learning satisfaction. Accordingly, the teacher's facial expression plays a key role in teaching students online. A number of tasks have been proposed that will contribute to the development of e-learning in Chinese higher education. The authors emphasize that in order to develop e-learning in Chinese higher education, it is necessary to pay attention to the following tasks: understanding and studying trends in the ICT development in education; targeting e-learning strategies at improving learning interests; constant monitoring and updating of software and hardware of higher educational institutions for introduction of new technologies in higher education; development and distribution of platforms with simple software interfaces for creating distance learning courses; development of information resources.
\end{abstract}

Keywords: adaptive learning; blended learning; distance education; e-learning tools; e-learning; higher education.

\section{INTRODUCTION}

The problem statement. Continuous progress and a growing demand in the field of Internet technologies have contributed to the popularity of e-learning. E-learning is believed 
to be a promising approach, since it offers students unique ways to interact with experienced teachers and professors [40].

According to Ambient Insight Research [3], there are two major trends in China's elearning market: the proliferation (and fail rate) of online education startups and the growing number of large Internet companies entering the market. Baidu, Alibaba, and Tencent are the largest Internet companies in China. They all entered the commercial e-learning and mobile learning markets in 2013 and 2014 and all of them are now adding mobile features or moving completely to mobile formats. Statistical data of iResearch Consulting Group shows that the revenue of China's online education market reached 251.76 billion Yuan in 2018 with a YoY growth of $25.7 \%$, which was estimated to keep a growth rate of $16 \%-24 \%$ in the following 3-5 years [30] (Figure 1).

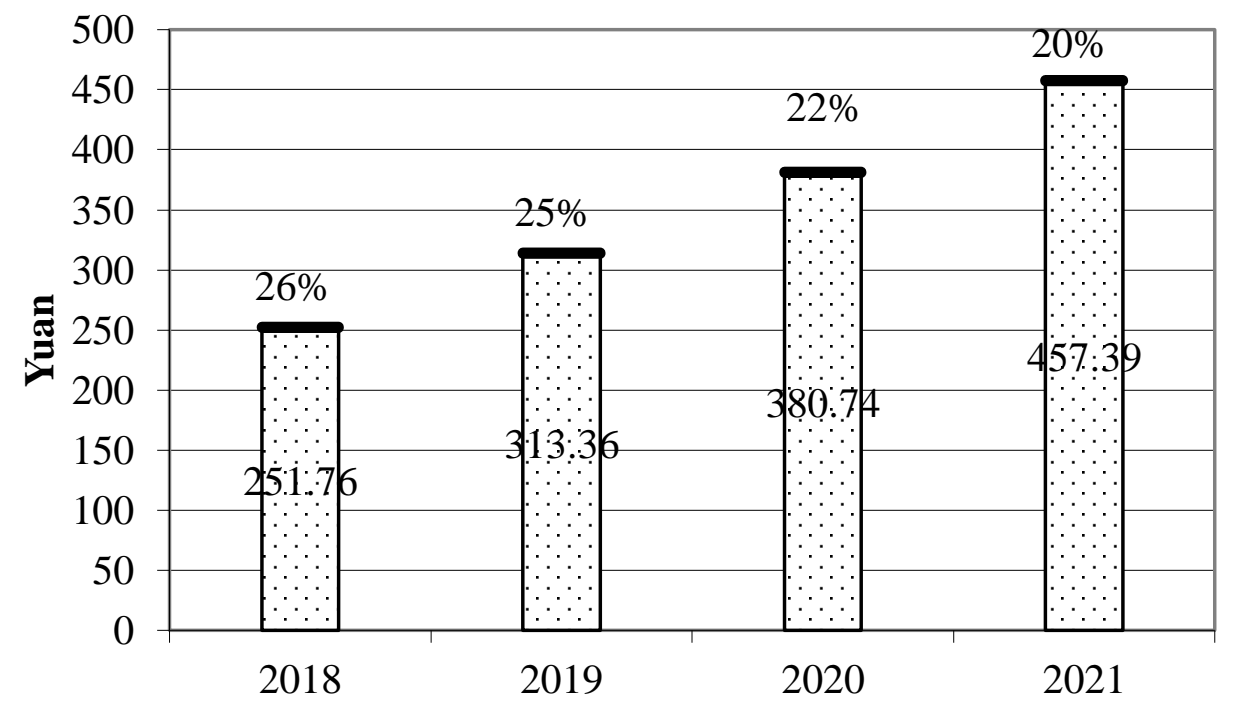

$\square$ Revenue of online education market $\mathbf{D}$ Growth of online education market

\section{Figure 1. Revenue of China's Online Education Market 2018-2021}

In addition, the Chinese education system has simultaneously undergone an unprecedented expansion and modernization. The number of enrolment in tertiary education increased from 1.9 million in 2013 to 2.3 million in 2018 (see http://data.uis.unesco.org).

In the context of the pandemic caused by the coronavirus infection, online education has become even more popular and relevant not only in corporate education, but also in higher education. Based on all this, taking into account that open and distance e-learning, as practiced by both open and residential universities in the region, can play a major role in transforming higher education [6], and in view of a large user base of educational services in China, the development potential of the online education market is large and it is growing. In this regard, there is a need to analyse the current status of electronic education, as well as its development trends in China.

The main components of e-learning are learning agents, learning tools, the learning discipline and the learning platform. The agents of learning are the student and teacher. Under e-learning conditions, the teacher switches to the role of a tutor, who in a higher educational institution should provide assistance to a future specialist in creating his/her own educational program taking into account the capabilities of a particular educational institution. He/she helps in the design of the student's individual educational trajectory, as well as in the development of individual research projects. The tutor acts as a key figure in e-learning, 
providing social and pedagogical support to students in the learning process using distance learning technologies, including information and communication ones [28].

The e-learning tools are various devices (personal computer, laptop, smartphone, tablet, wearable computer) and various computer software, web- and mobile applications. The advantage of modern e-learning is the ability to scale to different devices, and mobile technologies are especially convenient, as they allow users to undergo training anytime and anywhere. The object of training is an electronic course (its content), which can be presented in different ways: in the form of text, screencast (video with screen recording), a system of webinars, video courses, interactive simulators, slide courses, VR simulators or mixed technologies (text, graphics, video, etc.).

The learning platform is a means of interaction of agents with the object and learning tools. Usually this is a web resource (website) that contains training materials, a distance learning system (LMS, LCMS, e-learning platforms) [18] or a specialized system (Authoring Tools, for example Articulate, iSpring Suite, Adobe Captivate, Elucidat, isEazy WebTutor, Docebo etc.) [5]. By virtue of the skillful integration of these components and educational technology, e-learning turns out to be a holistic educational process that has a goal, means to achieve it and planned results.

Analysis of recent studies and publications. Numerous scientific papers and reports have dealt with the analysis of the e-learning experience in China. The review of Wang et al. [40] presents a clear picture on the development of e-learning in China and the challenges it faced in 2009. According to this research, three representation forms of e-learning were introduced in China up to 2009 - e-delivery, e-teaching and e-education. The country introduced innovative forms of professional development for millions of school teachers and principals, launched distance education colleges and web-based courses for self-directed learning. Blended learning approach has been implemented, which involves face-to-face sessions, online sessions, CD-ROM and internet resources. Four Special Issues of Journal of Educational Technology \& Society are dedicated to e-learning issues and present more than 90 articles. In their conclusions on the research of 2011, Lam et al. [20] state that e-learning has provided learning benefits to students. They base their statement on observing the behaviour of students who, the more they had experience working with e-learning strategies, the more positively they felt about it.

The analysis of the e-learning experience in China for 2013-2014 is presented in the report "2013-2014 Online Education User Behavior Analysis Report in China" [1]. According to the IResearch Institute study "China Educational Platform Research Report 2015" [2], the Chinese e-learning market is dynamically developing not only in the field of school education, but also in the area of professional, university, and corporate education. Although university eeducation is projected to decline, it continues to be over $50 \%$ (Figure 2). In the research of elearning in China [14] e-learning issues in higher education were not enough outlined.

The broader research of development of e-learning in China was carried out in 2018 by Wang, Liu, \& Zhang [39]. The research describes the history of formation of e-learning until 1990, opportunities and challenges for e-learning in China until 2012. It partially analysed scientific works and documents until 2018, more attention was paid to the national aspects of e-learning, but not to e-learning problems in Chinese higher education. 


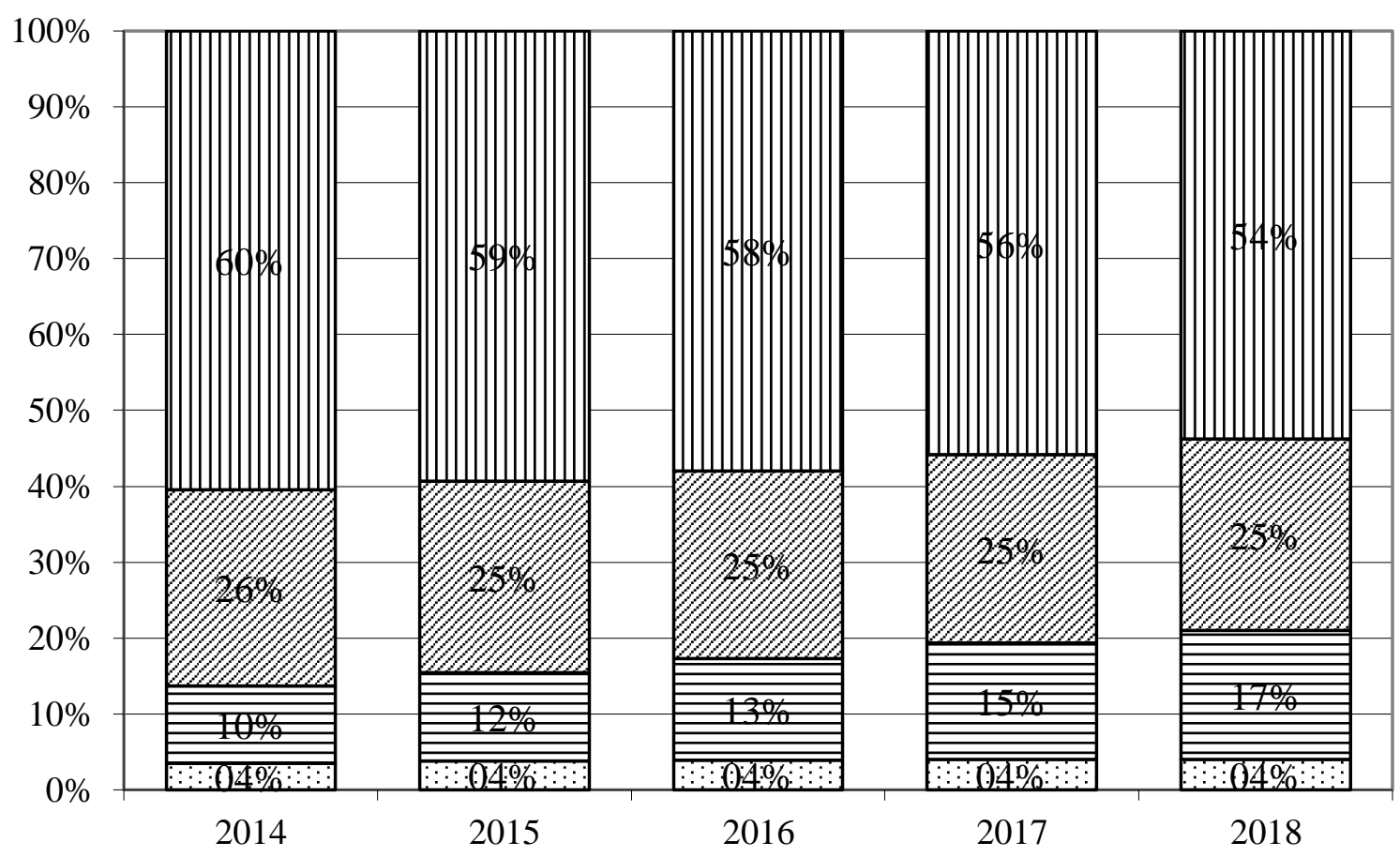

$\begin{array}{ll}\text { 凹Elearning in Higher Education } & \square \text { Professional Elearning } \\ \text { 日Elearning in primary and secondary schools } & \text { ■Elearning in enterprises }\end{array}$

Figure 2. E-learning segments in China for 2014-2018 (2016-2018forecast)

The research goal. Our research has the purpose to bridge the above-mentioned research gaps by investigating what scientists have achieved over the past 5 years in the study of effective e-learning tools in Chinese higher education. The following research questions need to be answered:

- What are the challenges in developing e-learning in China?

- What are the most effective e-learning technologies in higher education?

- What e-learning tools are most used and promising?

- What should Chinese higher education focus on in the process of introducing and developing e-learning?

\section{RESEARCH METHODS}

The research methodology has been implemented in three directions:

- The search in scientific databases (ERIC, WoS, Scopus) and analysis of scientific publications over the past 5 years, which reveal the issues of implementation, creation and use of e-learning in Chinese higher education. The search was carried out by the "e-learning in China' key phrase and limited by parameters such as date (2016-2020) and field of study (pedagogy, interdisciplinary research, computer science). Further, in the process of the metaanalysis, the most significant papers that clearly correspond to the research topic were identified and analysed.

- The study of the practical aspects of using e-learning tools in Chinese higher education through a survey of University teachers and students. For this purpose a questionnaire for teachers and students of Chinese universities was designed. The survey for teachers and students in its final 
form had a total of 10(8) forced-choice questions. Administration of the questionnaire was carried out online from mid-April to mid-May 2020 through Google Forms. An invitation to complete the online questionnaire was sent to teachers and students.

A total of 36 valid responses were collected (20 teachers and 16 students of science and technology majors). Statistical analyses were conducted by spreadsheets software (Google Sheets). The survey was anonymous and had the following two components related to the two aspects in our study:

1) use of distance learning systems and e-learning tools; in the first section, we aimed at finding out the use of various types of e-learning tools that teachers and students applied in their learning process;

2) perceptions of e-learning; in the second part, we studied teachers' and students' perceptions.

- The analysis of prospects of modern e-learning technologies that can be used in Chinese higher education and ways of their implementation in teaching practice at universities in China. The analysis was based on a review and synthesis of reports and scientific articles on emerging trends in e-learning.

\section{THE RESULTS}

The analysis of scientific publications for the last 5 years, which has been carried out in the ERIC, Web of Science (WoS) and Scopus bases, shows that the number of papers in ERIC and WoS decreases, and the number of papers in Scopus increases. The results show the number of documents that were retrieved using the keywords (ERIC) and advanced search options in the WoS and Scopus databases. "E-learning in China" was used as the search term. The search for e-learning adoption returned 17 results from ERIC, 35 from WoS and 534 from Scopus (Table 1). Due to the large number of results, a refined search was performed in the Scopus database by adding additional keywords - "higher education", "university" and "student". This reduced the results to 323.

Table 1

Summary of search results for e-learning adoption from ERIC, WoS and Scopus

\begin{tabular}{|c|c|c|c|c|}
\hline Year / Database & \multirow{2}{*}{ ERIC } & \multirow{2}{*}{ WoS } & \multicolumn{2}{|c|}{ Scopus } \\
\cline { 4 - 5 } & & & all & higher education \\
\hline 2020 & 1 & 4 & 32 & 19 \\
\hline 2019 & 1 & 7 & 156 & 97 \\
\hline 2018 & 5 & 5 & 130 & 70 \\
\hline 2017 & 4 & 11 & 131 & 51 \\
\hline 2016 & 6 & 8 & 85 & 323 \\
\hline Total & 17 & 35 & 534 & 116 \\
\hline
\end{tabular}

After the analysis of the content of articles found in the ERIC online library of education research and information, 7 studies have been excluded from 17 papers because they have not been related to higher education or disclosed the experience of e-learning in countries other than China. Of the 35 articles found by searching the Web of Science, 21 studies have been excluded from the review, for the same reason, and repetitions have been also excluded. In addition to searching for articles in scientific databases, a search has been made in the Journal of Educational Technology \& Society. In 20 issues for 2015-2019, 15 articles are devoted to the description of theoretical research and episodic experience of using e-learning tools in Chinese higher education. They have been included in the further analysis 
of papers found in Web of Science. Of the 323 articles found by Scopus, 207 studies have been excluded from the review.

We have also compared the contribution of Chinese scientists to the study of e-learning problems in higher education on a global scale. To do this, we have searched for the 'elearning' keyword in the WoS and Scopus bases and limited the above-indicated years (over the last 5 years) to areas of research (pedagogy, interdisciplinary research, computer science) and by country (separately China, separately other countries). For a more fair presentation of the contribution, we derived a contribution coefficient as the ratio of the number of articles on e-learning to the total number of articles for a certain period and a certain topic. By the analysis of the data obtained as a result of this search, by the number of articles in the WoS and Scopus databases, China occupies the second place after the United States. But, if we look at the context of the ratio of articles on e-learning in higher education and the total number of articles in the areas of research that we have chosen, which is determined by the coefficient, the contribution is less significant (Figure 3). This indicates an insufficient study of this issue by Chinese scientists.

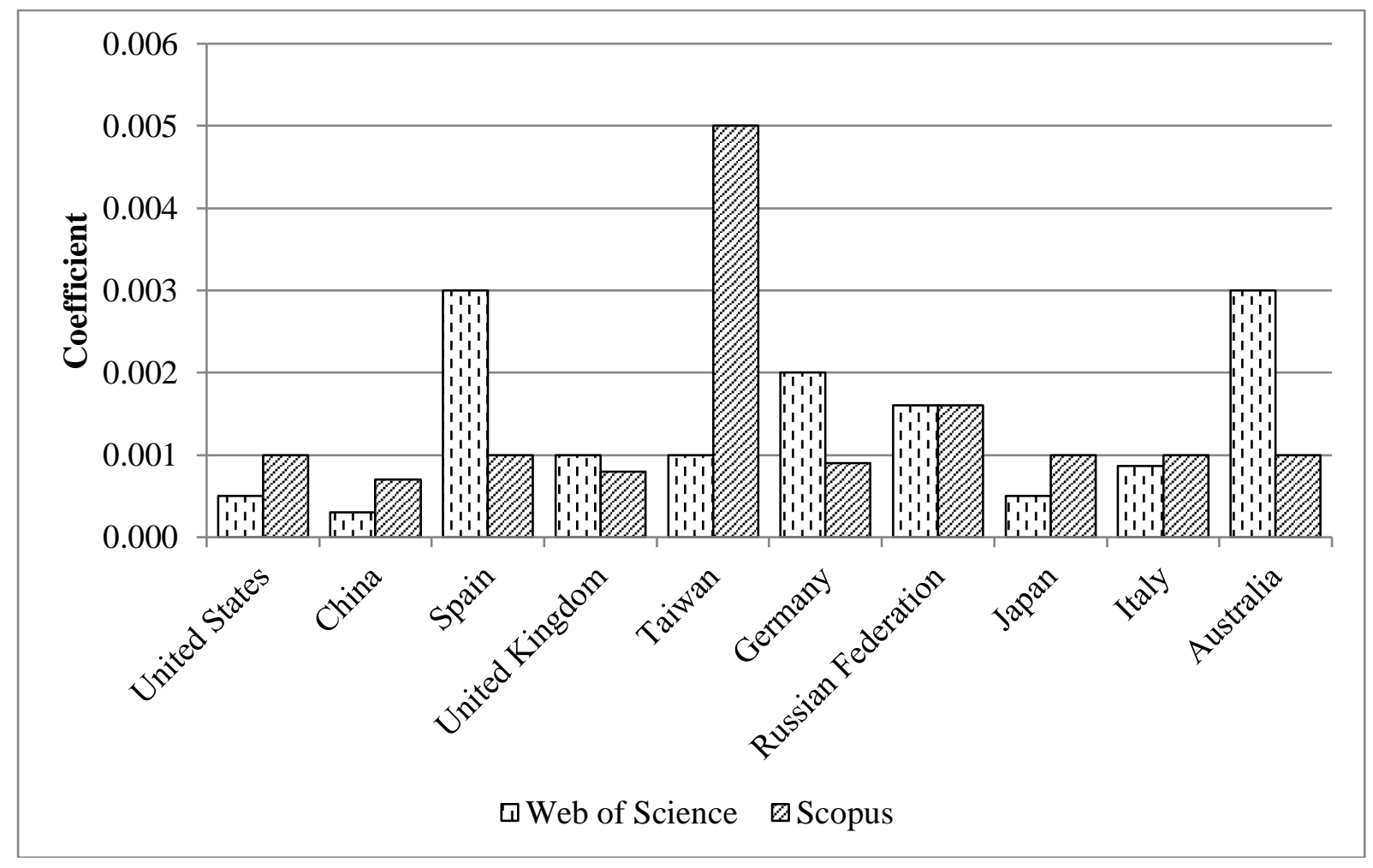

Figure 3. Distribution of country contribution to the research of e-learning in higher education according to the coefficient

\subsection{Meta-analysis of the papers on e-learning}

On the basis of the analysis of the papers that have been found as a result of various searches, we have identified 154 of the most significant studies over the past 5 years that reveal the issues of introducing, creating and using e-learning educational technology, and elearning tools in Chinese higher education. As a result of the analysis, grounding on the number of references in the selected articles, we have identified the most used pedagogical technologies in China (Blended Learning, Collaborative Learning, Flipped Classroom, MicroLearning and Adaptive learning) and the most popular e-learning tools (Mobile learning and 
technologies, Massive Open Online Courses, e-learning Environment, Online Platform, Gamified platform, Discussion forums and chats, Learning management system, Virtual technology, Learning Analytics and Big Data) (Table 3).

Table 3

E-learning educational technology and e-learning tools in papers

\begin{tabular}{|c|c|c|c|c|}
\hline Technology and tools / Database & ERIC & WoS & Scopus & $\begin{array}{c}\text { Total reference } \\
\text { number }\end{array}$ \\
\hline \multicolumn{5}{|c|}{ E-learning educational technology } \\
\hline Adaptive learning & - & 2 & 2 & 4 \\
\hline Flipped Classroom & - & 2 & 4 & 6 \\
\hline Active learning & - & 1 & - & 1 \\
\hline Collaborative learning & 1 & 3 & 2 & 6 \\
\hline Knowledge Map & - & 1 & - & 1 \\
\hline Badge evaluation & 1 & - & - & 1 \\
\hline Blended learning & 2 & 2 & 12 & 16 \\
\hline Micro-Learning & - & 2 & 3 & 5 \\
\hline e-learning 2.0 system & - & 1 & - & 1 \\
\hline Learning Analytics & - & 1 & - & 1 \\
\hline Personalized learning & - & 1 & 1 & 1 \\
\hline Micro-class & - & - & 2 & 2 \\
\hline Dialogic teaching & - & - & 1 & 1 \\
\hline Project-based learning & - & - & 1 & 1 \\
\hline \multicolumn{5}{|c|}{ e-learning Tools } \\
\hline Online classes, webinars & - & 1 & - & 1 \\
\hline Learning Analytics and Big Data & - & 3 & 3 & 6 \\
\hline Learning management system & 1 & 2 & 8 & 11 \\
\hline e-learning Environment, Online Platform & 1 & 1 & 15 & 17 \\
\hline Mobile technologies & 1 & 1 & 29 & 31 \\
\hline Multimedia learning & - & 1 & 1 & 2 \\
\hline Inquiry-Based learning & - & 1 & - & 1 \\
\hline Adaptive Systems & - & 1 & - & 1 \\
\hline Massive Open Online Courses (MOOC) & 1 & 3 & 20 & 24 \\
\hline Small Private Online Course & - & - & 1 & 1 \\
\hline Gamified platform & 1 & - & 4 & 5 \\
\hline Discussion forums, chats & 1 & - & 11 & 12 \\
\hline Cloud computing and technologies & - & 2 & 2 & 4 \\
\hline Video hosting service & - & 1 & 1 & 2 \\
\hline Virtual technology & - & - & 6 & 6 \\
\hline Internet of Things & - & - & 1 & 1 \\
\hline Smart Campus & - & - & 2 & 2 \\
\hline Virtual Reality & - & - & 4 & 4 \\
\hline Augmented Reality & & - & 2 & 2 \\
\hline Open Educational Resources & - & - & 2 & 2 \\
\hline Online conversational agent & - & - & 1 & 1 \\
\hline Artificial intelligence & - & - & 1 & 1 \\
\hline Online exercises & - & - & 1 & 1 \\
\hline Total number of articles & 7 & 31 & 116 & 185 \\
\hline
\end{tabular}

The analysis of these scientific studies suggests that e-learning covers various fields: pedagogical, philological, engineering, computer science, legal, agricultural, medical, and art majors, as well as majors related to sports and business. Both pedagogical and computer science studies pay attention to the information technologies that are used in e-learning. But in pedagogical papers, attention is paid to pedagogical technologies and e-learning methods, which is caused by the specifics of the subject area. Articles from other areas of research mostly describe mathematical models of e-learning (mathematics), psychological aspects of e-learning 
(psychology), business processes in e-learning (business, management and accounting), etc. Most of the works are concerned with learning English using e-learning tools. For example, a study by Liu and $\mathrm{Bu}$ [24] deals with aspects of learning a foreign language in the e-learning environment, but nevertheless it draws some very important conclusions:

- Students do not reach the required level of study in the e-learning due to frequent equipment failure or lack of interest in the online teaching resources which are identical to the textbook itself.

- Setting up an ideal e-learning environment alone is not enough.

- It is necessary to monitor students' individual learning process online and to facilitate their virtual communication activities so as to enhance reciprocal learning.

The conclusion made as a result of the research by Li et al. [21] is of great importance, it is stated that the priority of the roles and competencies has significantly changed, accompanied by the shift of pedagogy from cognitive behaviourism to social constructivism and connectivism. Deng et al. [12] claim that e-learning can convert theoretical concepts into easy understanding pictures, can make students willing to think and practice, it is helpful in facilitating their learning interests, can help students to develop the ability to survive and grow in the workplace, to learn independently, make innovations and use modern information technology. However, to achieve this, it is necessary to smooth out the negative aspects of elearning. For example, the lack of direct communication can be compensated with teacher's verbal behaviour [49].

Various online platforms are used to organize e-learning in higher education in China [15], including the gamified platform [16] and LMS [31]. They, as it is claimed by $\mathrm{Wu}$ [41], are tools to help members manage knowledge in an effective way. This research attempts to verify the constructs of knowledge creation self-efficacy, subjective norms, perceived usefulness, organizational climate, attitudes toward knowledge sharing and the intention to engage in knowledge sharing. It has been shown that in e-learning 2.0 systems knowledge creation selfefficacy, perceived usefulness and organizational climates have positive effects on the intentions toward knowledge sharing; factors of the communication quality and service quality influence the perceived usefulness of e-learning 2.0 systems; the intentions toward knowledge sharing in e-learning 2.0 have positive effects on the knowledge-sharing behaviour.

Another relevant issue is the introduction of massive open online courses (MOOC) in Chinese higher education. Foreign and national platforms are featured in the education market in the country. According to Zhang et al. [48], for the efficiency of the learning process the foreign platforms should emphasize ease of use more, and the national platforms should emphasize usefulness more, to enhance their attractiveness. At present, there are some important research problems, such as how to use MOOCs to solve China's educational equity issues, how to achieve the sustainable development and continuous innovation of China's MOOCs [33]. The main development of MOOCs takes place in different layers (higher education institutions, companies and associations), but the impact of MOOCs does not necessarily focus on teaching and learning, it is adopted in different ways to serve the needs of public and private sectors. The outlook for MOOCs is promising, as the Chinese government has promulgated a policy to accelerate the development of MOOCs [50] The "major advantages of MOOC teaching in China are reflected in the following ways: a lot of learners engage in learning, no space-time limit is imposed upon students in learning process, there is a wide coverage of curriculum, complete teaching program and integral teaching materials" [46, p. 208].

Mobile technologies in education have become of greater importance over the last 5 years. The WeChat is used instead of developing a new application to integrate with Moodle to provide students with a mobile learning environment [22]. The research results [43] showed that the group exposed to "Rain Classroom" (mobile application in China facilitating the didactic practice both synchronously and asynchronously in class) had a positive attitude 
towards the mobile technology tool. Also, the test group obtained statistically higher scores than the control group in both learning engagement and their willingness to continue and share the learning experience. So it has been proven that the mobile learning technology has a positive effect on teachers, students and institutions in terms of curriculum design, learning activities and policy making towards improving academic quality. These conclusions have been confirmed by Lin, who adds to this statement that to "achieve the desired effects of the mobile network learning mode, teachers should pay attention to three factors: the change of the teacher's role in the teaching process, the acquisition of mobile network applications in the new learning mode, and the support of exterior service technologies" [23, p. 170]. Application of mobile technologies contributes to collaborative learning. Specifically, Sun et al. [32] state that using the online discussion forum results in more communication aimed at knowledge construction, while using the mobile instant-messaging app results in more social interactions. Development of mobile learning in China can be possible due to the possibilities such as using wireless networks, social networks as interaction platforms, different quality content and establishing a comprehensive, dynamic and diversified evaluation mechanism [25].

Blended learning as one of the e-learning strategies is used at higher education institutions of China, it offers more flexibility and student support, enhances student engagement, thus improving student learning outcomes, and most importantly, increases the interaction between teachers and students [8]. This is confirmed by a number of scientific studies in the field of vocational training of specialists of various specialties [10], [23]. The flipped classroom is also an often used and efficient strategy in China. Tiejun notes that "application of flipped classroom teaching mode changes boring theory taught into exciting interactive teaching and learning, contributes to the development independence of students' thinking, learning autonomy and the ability to explore knowledge, transforms the relationship between teachers and students into learning partnerships" [34, p. 135].

With the development of adaptive learning technologies in the world, Chinese scientists have also contributed to their research mainly in the field of computer science. They have examined such issues as: adaptive resource prefetching with spatial-temporal and topic information for educational cloud storage [17], adaptive testing [36], complex adaptive systems theory [37], providing an adaptive online course in accordance with the knowledge of the learner [35] and others.

A small number of studies by Chinese scientists are concerned with data analysis problems in education, the use of virtual and augmented reality, Internet of Things (IoT) in elearning, although these technologies are important for the integration of China into the global information society. The need for the use of learning analysis technology is pointed out by some Chinese scientists. Zhang et al. state that learning analysis technology can standardize the assessment of learning outcomes, identify the main factors that affect the online learning outcomes and the group characteristics of online learners, provide the learners with personalized learning diagnosis reports, which can both help learners understand their own learning status and promote instructors' accurate teaching and reasonable valuation [47]. Chen et al. emphasize that immersive learning in Virtual Reality (VR) environments is the developing trend for future education systems including remote physical training, and strong VR presence can enhance students' learning experience [9]. In order to integrate Virtual and Remote Labs into teaching practice of engineering and science education efficiently, it is significant to improve the students' experience in virtual learning, the design and quality of the virtual space, the realism of the simulations and the diversity of the interaction [49]. Also researchers Xiao et al., [44] claim that students have higher learning satisfaction and behavioural willingness in AR-based experiential learning activities. So it can be seen that AR helps to stimulate students' interest in learning. 
The network teaching platform is a vital embodiment and component of the digitization construction of colleges and universities. Applying the big stack of technologies, including IоТ и 5G, Chinese scientists [45] have developed an online teaching platform (Smart Campus) based on the four initiatives operation model (government-led, college sponsor, subject teacher, and academic director). Thus, technologies for collecting data about students using IoT have been used, which allows us to talk about the introduction of this promising technology in Chinese higher education.

From the perspective of recent events in the world related to the COVID-19 pandemic, when many teachers have switched to using video lectures and video chats, the results of the study by Wang et al. [38] are important. It has been proven that video lectures with a heightened level of the instructor expressiveness were better than those with a conventional level of the instructor expressiveness and audio-only ones with regard to improving students' activity level and learning satisfaction. Accordingly, instructor's facial expressions have a key role in students' online learning. Issues of the potential of modern e-learning technologies have come in sight of researchers who studied e-learning at China's educational institutions. In 2013, the authors of [19] determined the following trends in educational technology through the lens of the highly cited articles published in the Journal of Educational Technology and Society: Dynamic media, Ubiquitous learning, Mobile learning, Forum analysis, e-learning, Mobile learning, Web 2.0, Blended learning, Web 2.0, Collaborative learning. Later (2020) six emerging technologies and practices that are beginning to have a significant impact on the future of postsecondary teaching and learning have been determined, namely: Adaptive Learning Technologies, AI/Machine Learning Education Applications, Analytics for Student Success, Elevation of Instructional Design, Learning Engineering, and UX Design, Open Educational Resources, XR (AR, VR, MR, Haptic) Technologies [7].

\subsection{Case study of e-learning tools}

In addition to the theoretical analysis of the experience of implementation, creation and use of e-learning in higher education in China, the study aimed to compare its results with the real situation at universities in China. For this, a survey of teachers and students has been conducted. As a result, 20 responses from teachers and 16 answers from students of science and technology majors of Anhui University have been received. The results of each research question are reported below (Figures 4-10).

\begin{tabular}{|c|c|}
\hline $\begin{array}{l}\text { RQ1. Is there an opportunity to provide e- } \\
\text { learning at your educational institution? (for } \\
\text { teachers) }\end{array}$ & $\begin{array}{l}\text { RQ1. Does your institution have the opportunity } \\
\text { to provide e-learning? (for students) }\end{array}$ \\
\hline$\underbrace{a}_{\text {वYes 日No øI don't know }}$ & $\begin{array}{c}\text { ๑Yes घNo øI don't know } \\
\text { b }\end{array}$ \\
\hline
\end{tabular}

Figure 4. Teacher (a) and student (b) opinions on accessibility of e-learning in their educational institution 
Participant responses (Figure 4) have shown that teachers and students to a large extent are given the opportunity to carry out e-learning at their educational institution. The discrepancy in the answers between teachers (85\% - yes) and students $(62.5 \%$ - yes) indicates that students are not sufficiently aware of the possibilities of e-learning at their educational institution.

The results have indicated (Figure 5) that majority of teachers $(85 \%)$ use e-learning tools in the teaching process, which has been confirmed by student opinions $(50 \%$ - yes, $43.8 \%$ ) - partially).

Next, we wanted to find out what forms of training are most often carried out in the practice of higher education in China. Answers from teachers (65\%) and students (93.8\%) indicate that blended learning is given priority (Figure 6).

\begin{tabular}{|c|c|}
\hline $\begin{array}{l}\text { RQ2. Do you use any e-learning tools in } \\
\text { your teaching process? (for teachers) }\end{array}$ & $\begin{array}{l}\text { RQ2. Do your teachers use e-learning tools in } \\
\text { the teaching process? (for students) }\end{array}$ \\
\hline 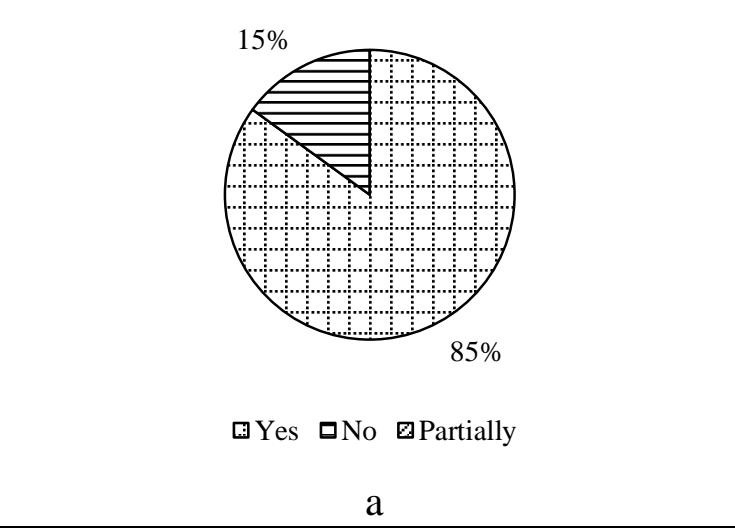 & 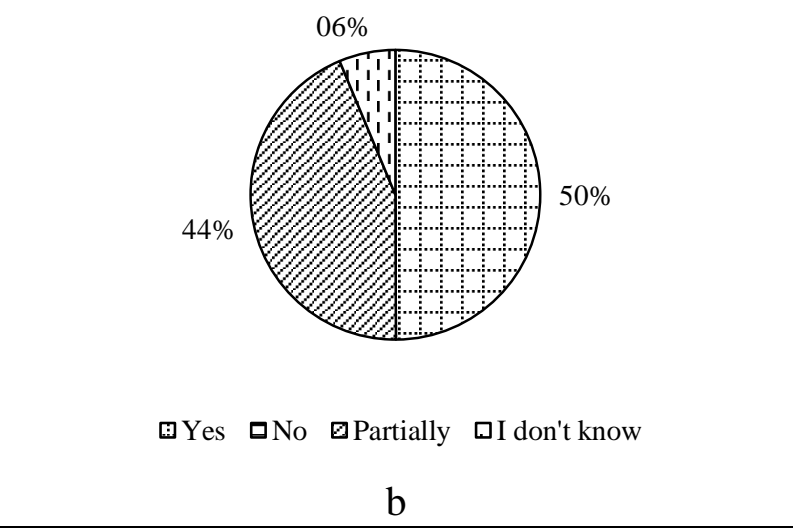 \\
\hline
\end{tabular}

Figure 5. Application of e-learning tools by teachers in the teaching process: teacher (a) and student (b) opinions

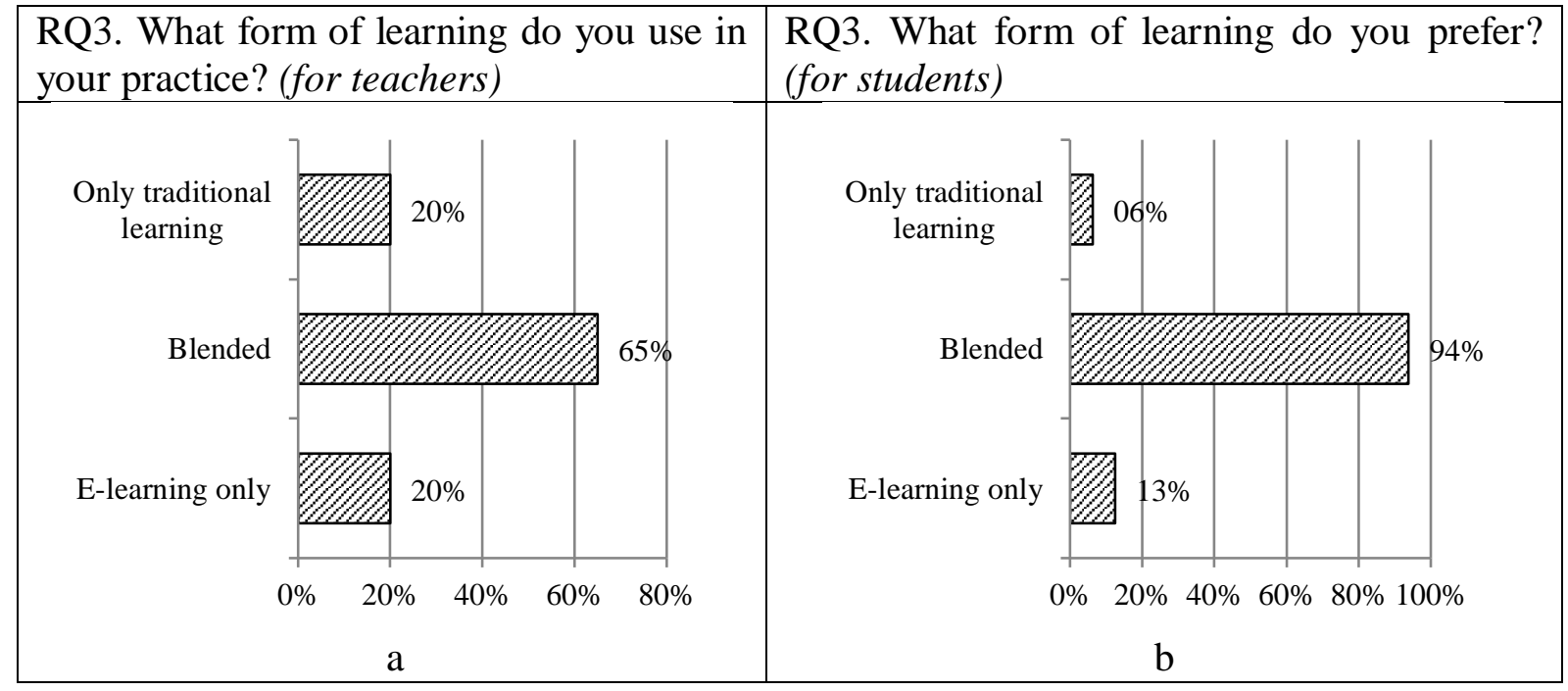

Figure 6. Information about the most used (a) / preferable (b) form of training

When organizing e-learning, the time that is spent on completing training tasks in the elearning environment or using the e-learning tools is a significant factor. This must be taken 
into account so that teachers and students do not become overloaded, and so as not to provoke the development of discomfort, stress or exhaustion from e-learning. On the basis of the responses to this question (Figure 7), 31.6\% of teachers and $43.8 \%$ of students use more than $50 \%$ of their time on e-learning and not many use $100 \%$ of the time for this $(10.5 \%$ are teachers, $6.3 \%$ - students).

\begin{tabular}{|c|c|}
\hline $\begin{array}{l}\text { RQ4. How much work time do you spend } \\
\text { supporting e-learning? (for teachers) }\end{array}$ & $\begin{array}{l}\text { RQ4. How much study time do you spend on } \\
\text { e-learning? (for students) }\end{array}$ \\
\hline 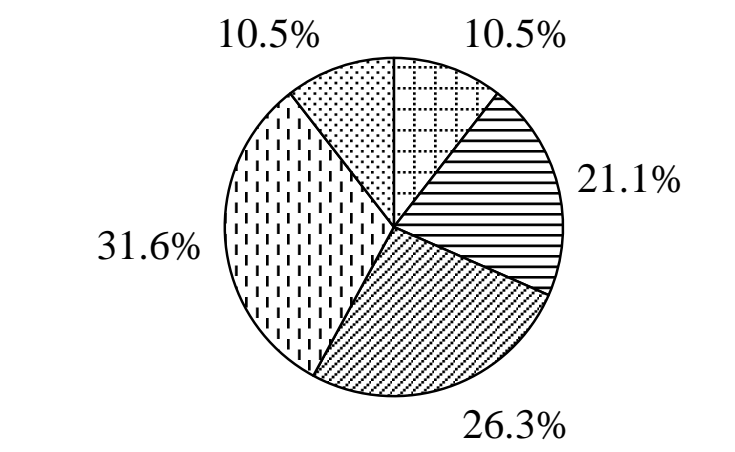 & $43.8 \%\left(\begin{array}{l}6.3 \% \\
0.3 \%\end{array}\right.$ \\
\hline 日Up to $50 \%$ & $\boxminus \mathrm{Up}$ to $50 \%$ \\
\hline 四More than $50 \%$ & $\square$ More than $50 \%$ \\
\hline 回 $100 \%$ & 国 $100 \%$ \\
\hline $\mathrm{a}$ & $b$ \\
\hline
\end{tabular}

Figure 7. Time spent on e-learning by teachers (a) and students (b)

This suggests a rational allocation of time for e-learning. At the same time, e-learning fatigue issues require further research.

Table 4

The most used e-learning platforms

\begin{tabular}{|l|l|}
\hline \multicolumn{1}{|c|}{ Questions } & \multicolumn{1}{|c|}{ Answers } \\
\hline $\begin{array}{l}\text { RQ5. Which e-learning } \\
\text { platforms do you prefer? } \\
\text { (for teachers) }\end{array}$ & $\begin{array}{l}\text { Blackboard (15.8\%), ATutor (10.5\%), Claroline (10.5\%), } \\
\text { Moodle (10.5\%), Zoom (15.8\%), WeChat (5.3\%), } \\
\text { DingTalk (5.3\%), Skype (5.3\%), Microsoft Team (5.3\%) } \\
\text { I do not know (15.8\%) } \\
\text { None (15.8\%) }\end{array}$ \\
\hline $\begin{array}{l}\text { RQ5. Which e-learning } \\
\text { platforms are used at your } \\
\text { educational institution? } \\
\text { (for students) }\end{array}$ & $\begin{array}{l}\text { Skype, Jitsi meet (25\%), Blackboard (6.3\%), Zoom } \\
(18.8 \%), \text { Claroline (6.3\%), E-mail (6.3\%) } \\
\text { I do not know (18.8\%) } \\
\text { None (18.8\%) }\end{array}$ \\
\hline
\end{tabular}

In addition, we have asked teachers what authoring tools they use to develop e-learning courses (RQ6). As a result, we have found that the most commonly used are Articulate 360 (20\%), Adapt (15\%), Adobe Captivate (5\%), Easygenerator (5\%), iSpring Suite (5\%).

Next, Figure 8 illustrates the answers to the question about the use of additional digital tools by teachers in e-learning. Most teachers $(84.2 \%)$ have given positive responses, and $56.3 \%$ of students have confirmed this with their answers, although $43.8 \%$ of students do not know whether teachers use e-learning tools other than those indicated above. 


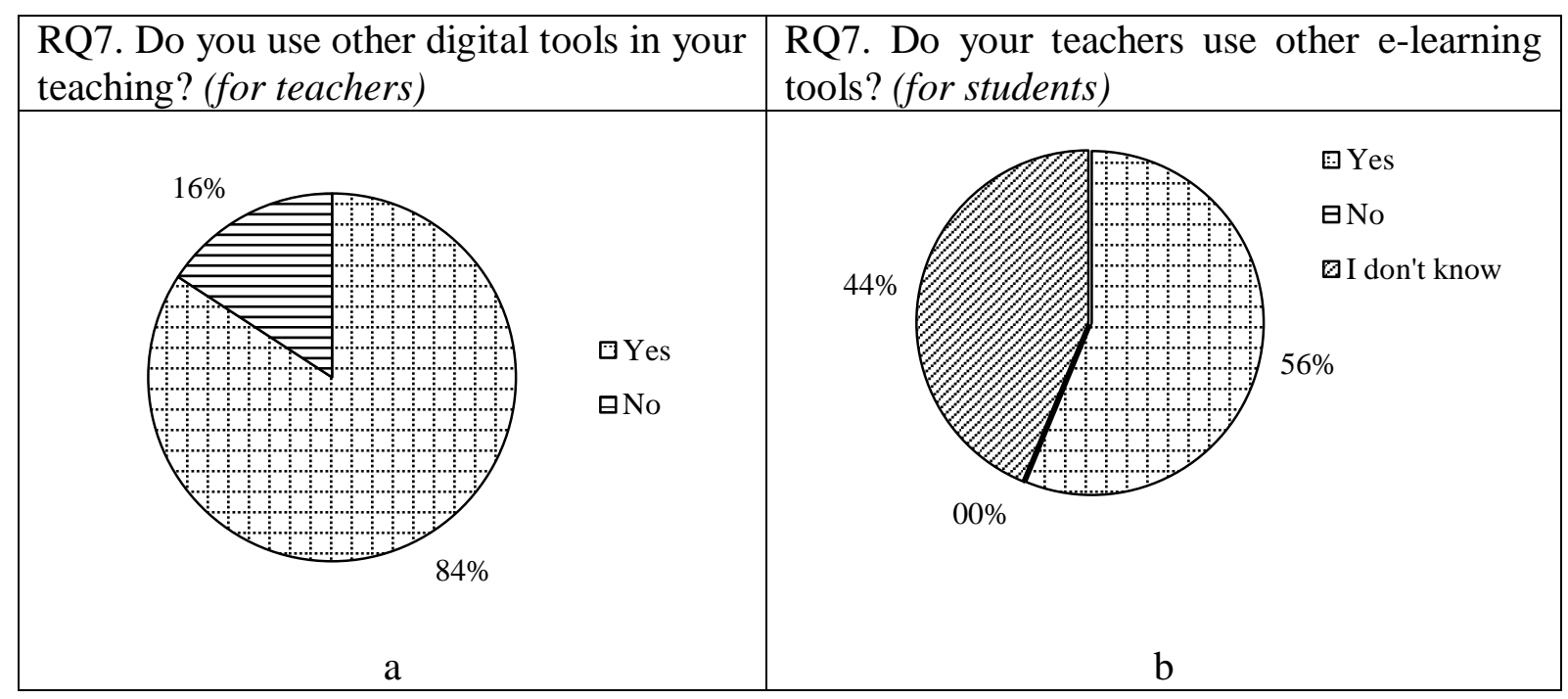

Figure 8. Details of other digital tools used by teachers (a) and students $(b)$ in e-learning

In question RQ8 for teachers, we have asked them to indicate the specific names of those digital tools that they use in e-learning. Messengers (WhatsApp, Skype, WeChat) (85\%) lead in the results of the responses, and then Video Hostings (YouTube, Youku, Tudou, meWATCH) (50\%), Social networks (Facebook, Douban, Cyworld, Instagram, TikTok) (45\%), E-mail (35\%), Teamwork services (online boards, online documents) (20\%), Learning websites (15\%), Microblogging (Twitter, Tumblr, Tencent Weibo) (10\%), Virtual reality (5\%) have been marked. Such technologies as Augmented reality and Cloud computing have not been named by respondents at all.

RQ9 (for teachers). Figure 9 presents the teachers' responses about how they mastered e-learning tools. Most teachers (60\%) claim that they have mastered e-learning tools on their own, 55\% have done it during university studies, $30 \%$ have mastered e-learning at special training courses at the educational institution where they work and at conferences and seminars, $25 \%$ have mastered e-learning with the advice of colleagues and only $5 \%$ of the respondents gained necessary skills during courses and trainings of a pedagogical association.

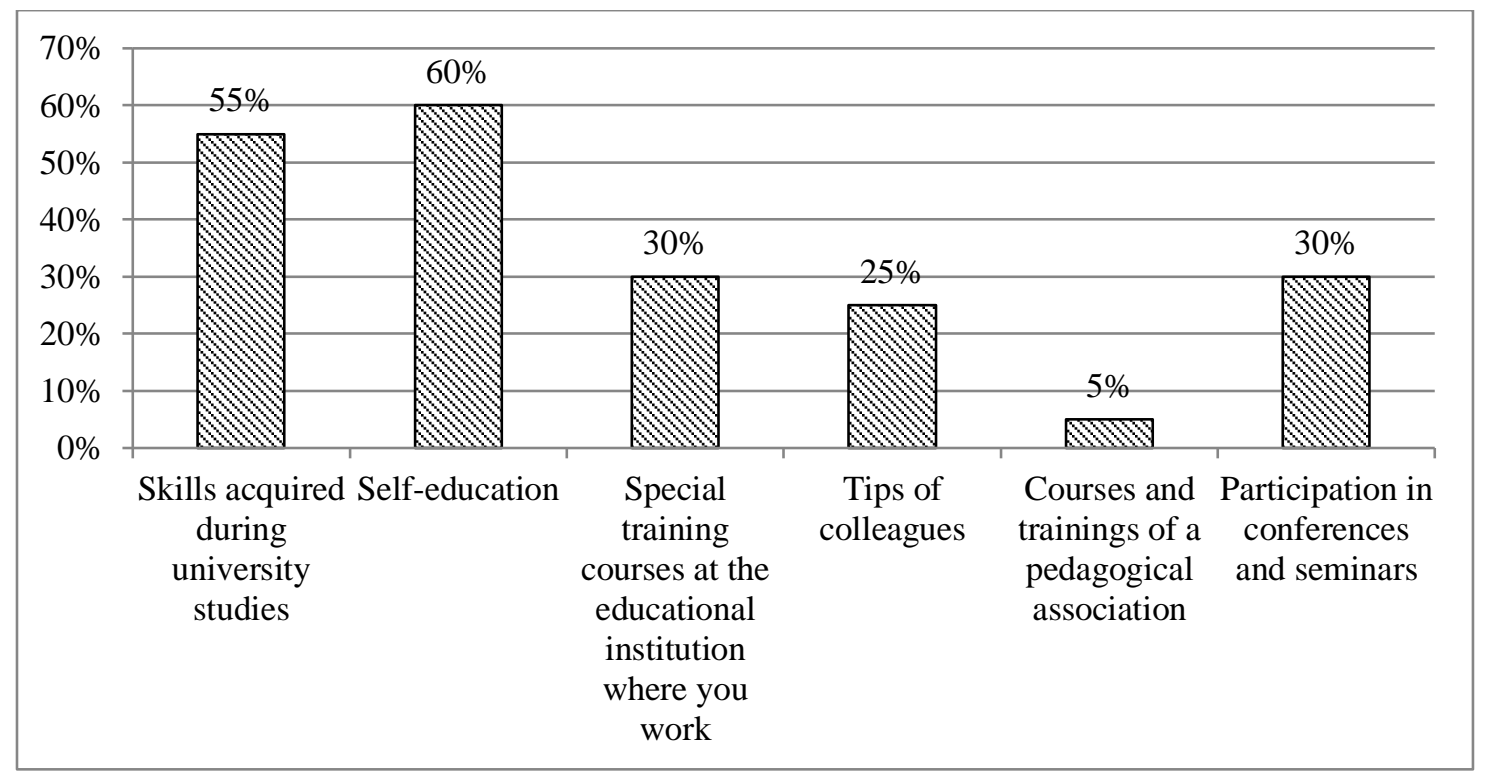

Figure 9. Ways of mastering e-learning tools by teachers 
Teachers' and students' perceptions of e-learning have been studied. The results of the analysis of the responses have shown that the majority of teachers $(65 \%)$ and students $(43.8 \%)$ have positive attitude towards e-learning (Figure 10).

\begin{tabular}{|c|c|}
\hline $\begin{array}{l}\text { RQ10. What do you think about e-learning? } \\
\text { (for teachers) }\end{array}$ & $\begin{array}{l}\text { RQ10. What do you think about e-learning? } \\
\text { (for students) }\end{array}$ \\
\hline 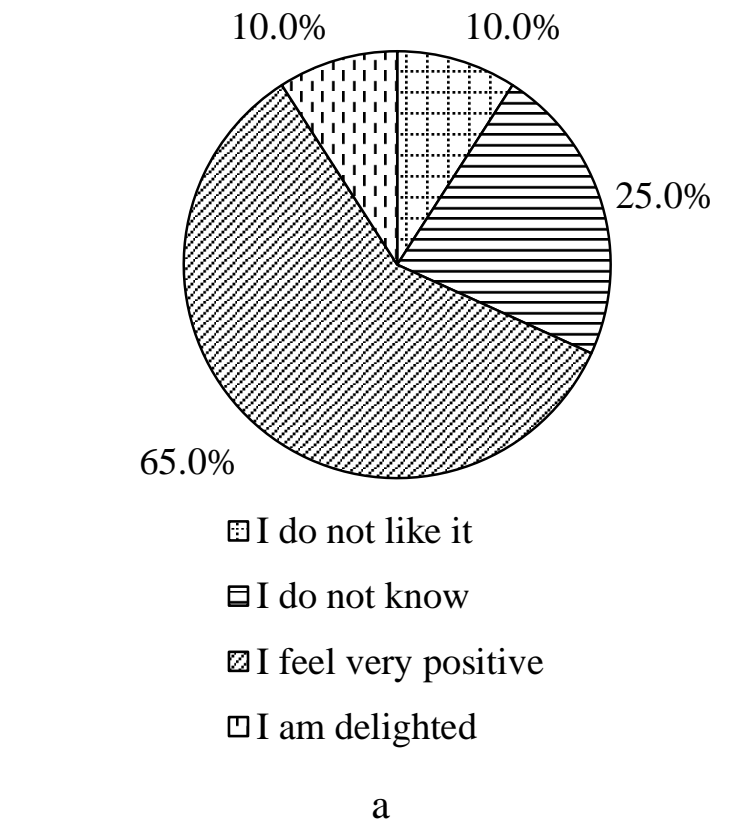 & 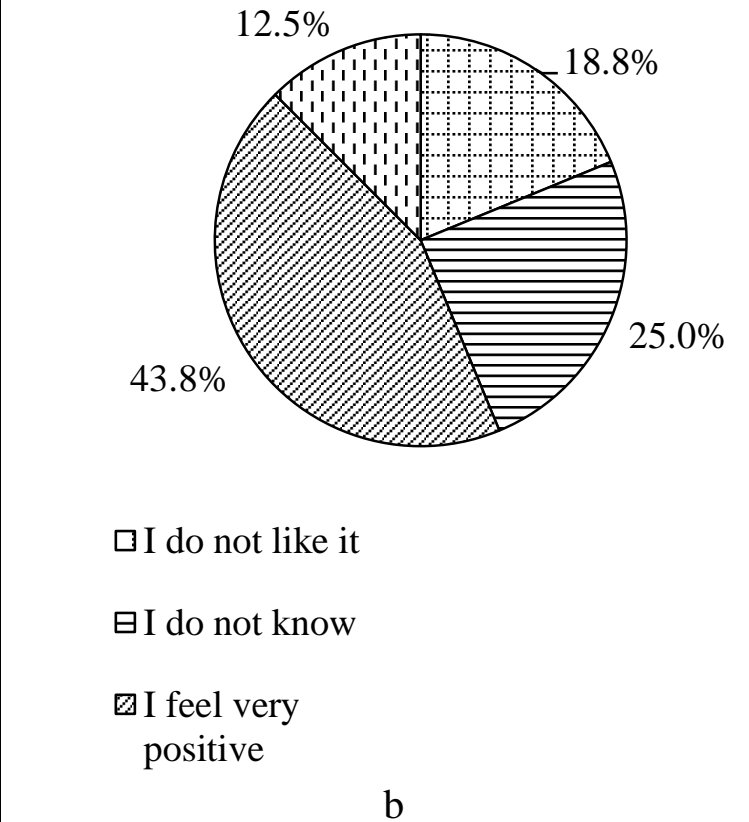 \\
\hline
\end{tabular}

Figure 10. Teacher (a) and student (b) opinions on e-learning

Thus, with the help of the survey, we have investigated the practical aspects of using various types of e-learning tools that teachers and students use in the learning process in higher education institutions in China, as well as how participants in the learning process perceive e-learning.

Based on our analysis of papers on e-learning educational technology, and e-learning tools in Chinese higher education by Chinese scientists, as well as referring to the results of our study of the practical aspects of using e-learning tools by Chinese students and teachers, it can be stated that these technologies are not examined and described enough. Development of trends of ICT use in education and their transformation into development strategies for higher education in China and the entire education system as a whole require additional reflection and research by Chinese scientists.

On the ground of the conducted research on e-learning in Chinese higher education, we do not support the opinion by McConnell that, despite enthusiasm by some for innovating elearning, the dominance of traditional teaching methods in China suggests that the conditions for mainstreaming e-learning in the near future are not strong [27]. According to Deloitte's estimation [11], China has a low penetration rate of Live streaming and Adaptive learning technology but there is a high penetration rate of Mobile App, VR/AR education and Online assistant technology in higher education. The government allocates huge funds to develop VR. This means that VR will be one of the highlights in integrating technology and education. But we agree that there are a number of factors inhibiting the learning technology market in China. According to analytics, Adkins states:

The primary inhibitor is so-called "regulatory uncertainty" with a growing number of regulations being imposed by the government, including the laws limiting screen time for children and laws prohibiting unapproved apps in the schools. There are also strict guidelines on the type of digital content allowed in the country [4]. 
We consider the following possible ways to solve these problems:

1. Comprehension and research of the trends in the development of ICT in education by Chinese scientists, turning them into development strategies for higher education in China [29].

2. Focusing the strategies of improvement of e-learning on the four following aspects: (1) the improvement of learning interests, (2) the use of hybrid learning methods, (3) the training of self-reflection and self-evaluation; and finally (4) the cooperative learning and sharing experience [42].

3. Development of research on promising technologies in education, such as Adaptive learning, AI/Machine Learning Education Applications, Analytics for Student Success, Elevation of Instructional Design, Learning Engineering, and UX Design, Open Educational Resources, XR (AR, VR, MR, Haptic) Technologies, also "Internet of things", nextgeneration management systems, natural user interfaces [7].

4. Use of direct efforts for improving the ICT skills of teachers and students, developing a systematic system for the training of specialists in the field of e-learning, taking into account current trends in the development of information and pedagogical technologies.

5. Constant monitoring and updating the software and hardware of higher education institutions for introduction of new technologies in higher education are necessary.

A number of measures recommended to improve Ukrainian higher education [29] can be introduced in China:

1. Organization of cooperation of developers of software products for e-learning, elearning methodologists and higher education institution teachers with the aim to develop strategies for the application of new information technologies in e-learning.

2. Development and distribution of platforms with intuitive, non-complex software interfaces for creating distance learning courses and e-learning software.

\section{CONCLUSIONS AND PROSPECTS FOR FURTHER RESEARCH}

The research has found that the most common educational technologies in Chinese higher education are blended learning, collaborative learning, modified classes, microlearning and adaptive learning, as well as e-learning tools such as mobile technology and mass open online courses. The findings of the study indicate that in spite of China's leading positions in e-learning financing and development and a wide research of e-learning problems by Chinese scientists, unresolved problems and insufficiently disclosed e-learning issues in Chinese higher education remain.

The survey of teachers and students of science and technology majors of Anhui University has shown difference between teachers' and students' opinions about the possibilities of e-learning at their educational institution. The survey results show that teachers more often carry out blended learning than distance learning, using a variety of elearning tools for this, such as Articulate 360, Adapt, Adobe Captivate, Easygenerator, iSpring Suite, as well as messengers (WhatsApp, Skype, WeChat), Video Hostings (YouTube, Youku, Tudou, meWATCH), social networks (Facebook, Douban, Cyworld, Instagram, TikTok) and E-mail. But at the same time, when teaching science and technology students, augmented reality and cloud computing technologies are not used enough. The results of this survey also provide the insight into teacher and student attitudes towards elearning and what factors contributed to teacher mastery of e-learning tools. The majority of teachers and students have positive attitude towards e-learning. Most Chinese teachers claim that they have mastered e-learning tools on their own.

The study of e-learning and its development strategies, ICT trends in Chinese higher education is a promising trend in pedagogical science, which may lead to solution of certain 
urgent tasks: understanding and studying trends in the ICT development in education; aiming learning strategies at the improvement of learning interests; constant monitoring and updating of software and hardware of higher educational institutions for introduction of new technologies in higher education; developing and distributing platforms with simple software interfaces for creating distance learning courses; developing information resources.

Some limitations can be found in the present study. Firstly, the search in scientific databases using selected keywords and areas of research might have overlooked some important scientific findings. Secondly, the survey has not covered the sufficient number of respondents, being limited to teachers and students of one university. Therefore, it is advisable to expand the geography of research in further studies.

\section{FUNDING}

The work is performed within the research on request of the Ministry of Education and Science of Ukraine, registration number 0120U101970.

\section{ACKNOWLEDGEMENT}

We thank Chen Chunxia for help in conducting the survey among students of Anhui University.

\section{REFERENCES (TRANSLATED AND TRANSLITERATED)}

[1] 2013-2014 Online Education User Behavior Analysis Report In China, 2014. [Online]. Available: https://www.prnewswire.com/news-releases/2013-2014-online-education-user-behavior-analysis-report-inchina-246837061.html. Accessed on: December 23, 2020 (in English)

[2] 2015 年中国在线教育平台研究报告, $2015 . \quad$ [Online]. Available: https://www.iresearch.com.cn/Detail/report?id=2490\&isfree=0. Accessed on: December 23, 2020 (in Chinese)

[3] S. S. Adkins, "The 2016-2021 Worldwide Self-paced eLearning Market: The Global eLearning Market in Steep Decline". Ambient Insight, (2016). [Online]. Available: https://uhlberg-advisory.de/wpcontent/uploads/2017/06/AmbientInsight_The-2016-2021_Worldwide_Self-paced-eLearning_Market.pdf. Accessed on: December 17, 2020 (in English)

[4] S. S. Adkins, "The 2019 Global Learning Technology. Investment Patterns: Another Record Shattering Year". Metaari Advanced Technology Research, 2020. [Online]. Available: https://seriousplayconf.com/wpcontent/uploads/2020/01/Metaari-2019-Global-Learning-Technology-Investment-Patterns.pdf. Accessed on: December 19, 2020 (in English)

[5] S. Asgari, \& A. Mehrpouyan, "A Group Comparison of E-learning Authoring Tools in Educational Production and Management". Indian Journal of Science and Technology, 11(24), pp. 1-6, 2018. doi:https://doi.org/10.17485/ijst/2018/v11i24/123052. (in English)

[6] M. d. P. Bandalaria, "Open and Distance eLearning in Asia: Country Initiatives and Instructional Cooperation for the Transformation of Higher education in the Region". Journal of Learning for Development, vol. 5, no. 2, pp. 116-132, 2018. (in English)

[7] M. Brown, M. McCormack, J. Reeves, D.C. Brook, S. Grajek, B. Alexander, M. Bali, S. Bulger, S. Dark, N. Engelbert, K. Gannon, A. Gauthier, D. Gibson, R. Gibson, B. Lundin, G. Veletsianos, \& N. Weber, "2020 Educause Horizon Report Teaching and Learning Edition”. Louisville, CO: EDUCAUSE, 2020. [Online]. Available: https://library.educause.edu/resources/2020/3/2020-educause-horizon-report-teaching-and-learningedition. Accessed on: December 27, 2020 (in English)

[8] W. Chen, "Incorporating Blended Learning in an Undergraduate English Course in China". In 4th International Conference on Education, Language, Art and Inter-cultural Communication (ICELAIC 2017), Atlantis Press, pp. 283-286, 2017. doi:https://doi.org/10.2991/icelaic-17.2017.64. (in English)

[9] X. Chen, Z. Chen, Y. Li, T. He, J. Hou, S. Liu \& Y. He, "ImmerTai: Immersive Motion Learning in VR Environments". Journal of Visual Communication and Image Representation, vol. 58, pp. 416-427, 2019. doi:https://doi.org/10.1016/j.jvcir.2018.11.039. (in English) 
[10] H. L. Chiu, "Materials Design and Pedagogy for Technology-Enhanced Language Learning. In Management Association", Online Course Management: Concepts, Methodologies, Tools, and Applications, pp. 1746-1760, 2018. doi:http://doi.org/10.4018/978-1-5225-5472-1.ch091. (in English)

[11] Deloitte China. A new era of education China education development report, 2018. [Online]. Available: https://www2.deloitte.com/content/dam/Deloitte/cn/Documents/technology-media-

telecommunications/deloitte-cn-tmt-china-education-development-en-report-2018.pdf. Accessed on: December 21, 2020 (in English)

[12] Q. Deng, Y. Li \& L. Zheng, "Digital education reform for improving interaction between students and instructors". In 14th Conference on Education and Training in Optics and Photonics, 29-31 May [104525Q], 10452, 2017. doi:https://doi.org/10.1117/12.2269871. (in English)

[13] Z.-G. Ge, A.-Y. Zhang,Y.-F. Li \& J. Su, "Exploring the Impact of Teachers' Verbal Immediacy as an Emotion Mediating Factor on Adult E-learners' Language Learning”. Educational Technology \& Society, vol. 22, no. 4, pp. 77-89, 2019. (in English)

[14] M. A. Guleva, "Electronic Education in China". Asia and Africa today, 3(716), pp. 21-24, 2017. (in English)

[15] C. Hu, "Application of E-Learning Assessment Based on AHP-BP Algorithm in the Cloud Computing Teaching Platform”. International Journal of Emerging Technologies in Learning, vol. 11, no. 08, pp. 27-32, 2016. doi:https://doi.org/10.3991/ijet.v11i08.6039. (in English)

[16] L. Huang \& Y. Yeh, "Meaningful Gamification for Journalism Students to Enhance Their Critical Thinking Skills". In Management Association, I. (Ed.), Online Course Management: Concepts, Methodologies, Tools, and Applications, pp. 1335-1351, 2018. doi: http://doi.org/10.4018/978-1-5225-5472-1.ch070. (in English)

[17] Q. Huang, C. Huang, J. Huang \& H. Fujita, "Adaptive resource prefetching with spatial-temporal and topic information for educational cloud storage systems". Knowledge-Based Systems, vol. 181, [104791], 2019. doi:https://doi.org/10.1016/j.knosys.2019.05.034. (in English)

[18] M. K. Keleş \& S. A. Özel, “A Review of Distance Learning and Learning Management Systems". Virtual Learning, 2016. doi:https://doi.org/10.5772/65222. (in English)

[19] H.-W. Kinshuk, Huang, D. Sampson \& N.-S. Chen, Trends in Educational Technology through the Lens of the Highly Cited Articles Published in the Journal of Educational Technology and Society". Educational Technology \& Society, vol. 16 no. 2, pp. 3-20, 2013. (in English)

[20] P. Lam, J. Lee, M. Chan \& C. McNaught, "Students' use of eLearning strategies and their perceptions of eLearning usefulness". Proceedings of Global Learn Asia Pacific 2011- Global Conference on Learning and Technology, pp. 1379-1388, 2011. (in English)

[21] S. Li, J. Zhang, C. Yu \& L. Chen, "Rethinking Distance Tutoring in e-Learning Environments: A Study of the Priority of Roles and Competencies of Open University Tutors in China". International Review of Research in Open and Distributed Learning, vol. 18, no. 2, pp. 189-212, 2017. doi:https://doi.org/10.19173/irrodl.v18i2.2752. (in English)

[22] Z. Li, Y. Fan \& J. Jiao, "Integrate WeChat with Moodle to provide a mobile learning environment for students". In International Conferences on Internet Technologies \& Society (ITS), Education Technologies (ICEduTECH), and Sustainability, Technology and Education (STE), pp. 142-149, 2016. (in English)

[23] W. Lin, "Exploring the convergence of the mobile learning mode in network environment and the traditional classroom teaching mode". International Journal of Emerging Technologies in Learning, vol. 12, no. 07, pp. 170-181, 2017. doi:https://doi.org/10.3991/ijet.v12i07.7248. (in English)

[24] A. Liu \& Y. Bu, "Reciprocal Learning Strategy in CALL Environment: A Case Study of EFL Teaching at X University in Shanghai”. Universal Journal of Educational Research, vol. 4, no. 5, pp. 1059-1070, 2016. doi:https://doi.org/10.13189/ujer.2016.040516. (in English)

[25] L. Liu, L. Zhang, P. Ye \& Q. Liu, "Influence factors of satisfaction with mobile learning APP: An empirical analysis of China". International Journal of Emerging Technologies in Learning, vol. 13, no. 03, pp. 87-99, 2018. doi:https://doi.org/10.3991/ijet.v13i03.8381. (in English)

[26] L. Luo, X. Cheng, Sh. Wang, J. Zhang, W. Zhu, J. Yang \& P. Liu, "Blended learning with Moodle in medical statistics: an assessment of knowledge, attitudes and practices relating to e-learning". BMC Medical Education, vol. 17, no.170, 2017. doi:http://doi.org/10.1186/s12909-017-1009-x. (in English)

[27] D. McConnell, "E-learning in Chinese higher education: the view from inside". Higher Education, vol. 75, pp. 1031-1045, 2018. doi:https://doi.org/10.1007/s10734-017-0183-4. (in English)

[28] K. Osadcha, "The Problem of Tutor Profession Institutionalization in the Ukrainian Educational Space". Ukrainian Journal of Educational Studies and Information Technology, vol. 6, no. 1, pp. 77-88, 2018. doi:https://doi.org/10.32919/uesit.2018.01.06. (in Ukrainian)

[29] V. V. Osadchyi \& K. P.Osadcha, "Modern realities and trends of information and communication technologies development in education". Information Technologies and Learning Tools, vol. 48, no. 4, pp. 47-57, 2015. doi:https://doi.org/10.33407/itlt.v48i4.1252. (in Ukrainian)

[30] Revenue of China's Online Education Market Increased by 25.7\% in 2018, 2019. [Online]. Available: http://www.iresearchchina.com/content/details7_53029.html. Accessed on: December 22, 2020 (in English) 
[31] X. Shi, "A comparative study of e-learning platform in reading and translating course for engineering students”. International Journal of Emerging Technologies in Learning, vol. 11, no. 04, pp. 120-125, 2016. doi:https://doi.org/10.3991/ijet.v11i04.5551. (in English)

[32] Z. Sun, C.-H. Lin, M. Wu, J. Zhou \& L. Luo, "A tale of two communication tools: Discussion-forum and mobile instant-messaging apps in collaborative learning”. British Journal of Educational Technology, vol. 49, no. 2, pp. 248-261, 2018. doi:https://doi.org/10.1111/bjet.12571. (in English)

[33] J. Tian \& Z. Xia, "MOOCs in China's universities: Practice, characteristics and trends". In 3rd International Conference on Information Management $\quad$ (ICIM), $\quad$ pp. $\quad 378-382, \quad 2017$. doi:https://doi.org/10.1109/INFOMAN.2017.7950412. (in English)

[34] Z. Tiejun, "Creative merging and practical application of "history of modern design" course online teaching platform construction and flipped classroom teaching mode". International Journal of Emerging Technologies in Learning, vol. 12, no. 2, pp. 118-136, 2017. doi:https://doi.org/10.3991/ijet.v12i02.6318. (in English)

[35] H. Ueda, M. Furukawa, K. Yamaji \& M. Nakamura, "SCORMAdaptiveQuiz: Implementation of Adaptive eLearning for Moodle". Procedia Computer Science, vol. 126, pp. 2261-2270, 2018. doi: https://doi.org/10.1016/j.procS.2018.07.223. (in English)

[36] C. Wang \& H. Lu, 'Mediating Effects of Individuals' Ability Levels on the Relationship of ReflectiveImpulsive Cognitive Style and Item Response Time in CAT'. Educational Technology \& Society, vol. 21, no. 4, pp. 89-99, 2018. (in English)

[37] Y. Wang, X. Han \& J. Yang, "Revisiting the Blended Learning Literature: Using a Complex Adaptive Systems Framework". Educational Technology \& Society, vol. 18, no. 2, pp. 380-393, 2015. (in English)

[38] Y. Wang, Q. Liu, W. Chen, Q. Wang \& D. Stein, 'Effects of instructor's facial expressions on students' learning with video lectures". British Journal of Educational Technology, vol. 50, no. 3, pp. 1381-1395, 2019. doi: https://doi.org/10.1111/bjet.12633. (in English)

[39] Y. Wang, X. Liu \& Z. Zhang, "An overview of e-learning in China: History, challenges and opportunities". Research in Comparative and International Education, vol. 13, no. 1, pp. 195-210, 2018. doi: https://doi.org/10.1177/1745499918763421. (in English)

[40] Q. Wang, Z. Zhu, L. Chen \& H. Yan, "E-learning in China". Campus-Wide Information Systems, vol. 26, no. 2, pp. 77-81, 2009. doi:https://doi.org/10.1108/10650740910946783. (in English)

[41] B. Wu, "Identifying the Influential Factors of Knowledge Sharing in E-Learning 2.0 Systems". International Journal of Enterprise Information Systems, vol. 12, no. 1, pp. 85-102, 2016. (in English)

[42] B. Wu \& T. Duan, "eLearning situations and cultivation strategies: an example from China". In 9th International Conference on E-Education, E-Business, E-Management and E-Learning, pp. 15-19, 2018. doi: https://doi.org/10.1145/3183586.3183599. (in English)

[43] L. Xiangming \& S. Song, "Mobile technology affordance and its social implications: A case of 'Rain Classroom",. British Journal of Educational Technology, vol. 49, no. 2, pp. 276-291, 2018. doi: https://doi.org/10.1111/bjet.12586. (in English)

[44] J. Xiao, M. Cao, X. Li \& P. Hansen, "Assessing the Effectiveness of the Augmented Reality Courseware for Starry Sky Exploration”. International Journal of Distance Education Technologies, vol. 18, no. 1, pp. 19-35, 2020. doi: https://doi.org/10.4018/IJDET.2020010102. (in English)

[45] X. Xu, D. Li, M. Sun, S. Yang, S. Yu, Manogaran, G., Mastorakis, G., \& Mavromoustakis, C. X. "Research on Key Technologies of Smart Campus Teaching Platform Based on 5G Network". IEEE Access, vol. 7, pp. 20664-20675, 2019. doi:https://doi.org/10.1109/ACCESS.2019.2894129. (in English)

[46] X. Yang \& Z. Song, "College Students' Law Education Platform Based on Browser/Server and Massive Open Online Courses”. International Journal of Emerging Technologies in Learning, vol. 14, no. 15, pp. 202-210, 2019. doi: https://doi.org/10.3991/ijet.v14i15.11153. (in English)

[47] J.-H. Zhang, Y.-X. Zhang, Q. Zou \& S. Huang, "What Learning Analytics Tells Us: Group Behavior Analysis and Individual Learning Diagnosis based on Long-Term and Large-Scale Data". Educational Technology \& Society, vol. 21, no. 2, pp. 245-258, 2018. (in English)

[48] M. Zhang, S. Yin, M. Luo \& W. Yan, "Learner control, user characteristics, platform difference, and their role in adoption intention for MOOC learning in China". Australasian Journal of Educational Technology, vol. 33, no. 1, pp. 114-133, 2017. doi: https://doi.org/10.14742/ajet.2722. (in English)

[49] M. Zhang \& Y. Li, "Students' Continuance Intention to Experience Virtual and Remote Labs in Engineering and Scientific Education”. International Journal of Emerging Technologies in Learning, vol. 14, no. 17, pp. 415, 2019. doi: https://doi.org/10.3991/ijet.v14i17.10799. (in English)

[50] Q. Zheng, L. Chen \& D. Burgos, "Emergence and Development of MOOCs. In The Development of MOOCs in China". Lecture Notes in Educational Technology, pp. 11-24, 2018. doi: https://doi.org/10.1007/978-981-106586-6_2. (in English) 


\title{
СУЧАСНИЙ СТАН ТА ТЕНДЕНЦІЇ РОЗВИТКУ ЕЛЕКТРОННОГО НАВЧАННЯ В КИТАЇ
}

\section{Осадча Катерина Петрівна}

доктор педагогічних наук, доцентка кафедри інформатики і кібернетики

Мелітопольський державний педагогічний університет ім. Б. Хмельницького, м. Мелітополь, Україна

ORCID ID 0000-0003-0653-6423

okp@mdpu.org.ua

\section{Осадчий Вячеслав Володимирович}

доктор педагогічних наук, професор кафедри інформатики і кібернетики

Мелітопольський державний педагогічний університет ім. Б. Хмельницького, м. Мелітополь, Україна ORCID ID 0000-0001-5659-4774

osadchyi@mdpu.org.ua

\section{Спірін Олег Михайлович}

доктор педагогічних наук, професор, член-кореспондент НАПН України,

проректор з наукової роботи та цифровізації

Державний заклад вищої освіти "Університет менеджменту освіти" НАПН України, м. Київ Україна ORCID ID 0000-0002-9594-6602

oleg.spirin@gmail.com

\begin{abstract}
Анотація. Поява нових технологій електронного навчання вимагає переосмислення їх впровадження у вищій освіті. Щоб заповнити цю прогалину, дослідження присвячено аналізу досвіду створення та використання засобів електронного навчання в закладах вищої освіти Китаю за останні 5 років. Опитування показало, що найпоширенішими освітніми технологіями у вищій школі Китаю є змішане навчання, спільне навчання, модифіковані класи, мікронавчання та адаптивне навчання, а також електронні засоби навчання, такі як мобільні технології та масові відкриті онлайн курси. Завдяки опитуванню викладачів університету та студентів досліджувались практичні можливості використання засобів електронного навчання в китайській вищій освіті. Результати аналізу відповідей викладачів та студентів науково-технічної освіти показали наступне: викладачі мають можливість організовувати електронне навчання у своєму університеті, змішане навчання в основному впроваджується в навчальний процес, викладачі не обмежуються вибором електронних інструментів навчання: відеоінструментів, месенджерів, соціальних мереж та інструментів електронного навчання, таких як Articulate 360 та Adapt. Доведено, що відеолекції з вищим рівнем висловлювання викладача були кращими за ті, що мали нормальний рівень висловлювання викладача та лише звук, з точки зору підвищення рівня вмотивованості студентів та рівня їх задоволення від навчання. Відповідно, вираз обличчя викладача відіграє ключову роль у навчанні учнів в Інтернеті. Запропоновано низку завдань, які сприятимуть розвитку електронного навчання в китайській вищій освіті. Автори наголошують, що для розвитку електронного навчання в китайській вищій школі необхідно звернути увагу на такі завдання: розуміння та вивчення китайськими вченими тенденцій розвитку IКТ в освіті; стратегії вдосконалення електронного навчання повинні бути спрямовані на покращення навчальних інтересів; необхідний постійний моніторинг та оновлення програмного та апаратного забезпечення вищих навчальних закладів для впровадження нових технологій у вищій школі; розробка та розповсюдження платформ із простими програмними інтерфейсами для створення курсів дистанційного навчання; розвиток інформаційних ресурсів.
\end{abstract}

Ключові слова: адаптивне навчання; змішане навчання; дистанційна освіта; засоби електронного навчання; електронне навчання; вища освіта. 


\title{
СОВРЕМЕННОЕ СОСТОЯНИЕ И ТЕНДЕНЦИИ РАЗВИТИЯ ЭЛЕКТРОННОГО ОБУЧЕНИЯ В КИТАЕ
}

\section{Осадчая Екатерина Петровна}

доктор педагогических наук, доцент кафедры информатики и кибернетики

Мелитопольский государственный педагогический университет им. Б. Хмельницкого, г. Мелитополь, Украина

ORCID ID 0000-0003-0653-6423

okp@mdpu.org.ua

\section{Осадчий Вячеслав Владимирович}

доктор педагогических наук, профессор кафедры информатики и кибернетики

Мелитопольский государственный педагогический университет им. Б. Хмельницкого, г. Мелитополь, Украина

ORCID ID 0000-0001-5659-4774

osadchyi@mdpu.org.ua

\section{Спирин Олег Михайлович}

доктор педагогических наук, профессор, член-корреспондент НАПН Украины

проректор по научной работе и цифровизации

Государственное учреждение высшего образования "Университет менеджмента образования" НАПН

Украины, г. Киев, Украина

ORCID ID 0000-0002-9594-6602

oleg.spirin@gmail.com

\begin{abstract}
Аннотация. Появление новых технологий электронного обучения требует переосмысления их внедрения в высшем образовании. Чтобы восполнить этот пробел, исследование посвящено анализу опыта использования и создания средств электронного обучения в учреждениях высшего образования Китая за последние 5 лет. Опрос показал, что наиболее распространенными образовательными технологиями в высшей школе Китая являются смешанное обучение, совместное обучение, модифицированные классы, микрообучение и адаптивное обучение, а также электронные средства обучения, такие как мобильные технологии и массовые открытые онлайн-курсы. Благодаря опросам преподавателей университета и студентов исследовались практические возможности использования средств электронного обучения в высшем образовании Китая. Результаты анализа ответов преподавателей и студентов научно-технического образования показали следующее: преподаватели имеют возможность организовывать электронное обучение в своем университете, смешанное обучение в основном внедряется в учебный процесс, преподаватели не ограничиваются выбором электронных инструментов обучения: видеоинструментов, мессенджеров, социальных сетей и инструментов электронного обучения, таких как Articulate 360 и Adapt. Доказано, что видеолекции с высоким уровнем высказывания преподавателя были лучше тех, что имели нормальный уровень высказывания преподавателя и только звук, с точки зрения повышения уровня мотивированности студентов и уровня их удовлетворения от обучения. Соответственно, выражение лица преподавателя играет ключевую роль в обучении в Интернете. Предложен ряд задач, способствующих развитию электронного обучения в высшем образовании Китая. Авторы отмечают, что для развития электронного обучения в китайской высшей школе необходимо обратить внимание на следующие задачи: понимание и изучение китайскими учеными тенденций развития ИКТ в образовании; стратегии совершенствования электронного обучения должны быть направлены на улучшение учебных интересов; необходим постоянный мониторинг и обновление программного и аппаратного обеспечения высших учебных заведений для внедрения новых технологий в высшей школе; разработка и распространение платформ с простыми программными интерфейсами для создания курсов дистанционного обучения; развитие информационных ресурсов.
\end{abstract}

Ключевые слова: адаптивное обучение; смешанное обучение; дистанционное образование; средства электронного обучения; электронное обучение; высшее образование.

\section{$(\mathrm{cc}) \mathrm{EY-NC-SA}$}

This work is licensed under Creative Commons Attribution-NonCommercial-ShareAlike 4.0 International License. 